J. Asiat. Soc. Bangladesh, Sci. 44(1): 53-60, June 2018

\title{
BIOCHEMICAL COMPOSITION OF SOME SELECTED AQUATIC MACROPHYTES UNDER EX-SITU CONDITIONS
}

\author{
HARICH AND HAZRA ${ }^{1}$, MD. ALMUJADDADE ALFASANE ${ }^{1 *}$, SHARMIN KAUSER ${ }^{2}$, UMME \\ FATEMA SHAHJADEE ${ }^{3}$ AND MONIRUZZAMAN KHONDKER ${ }^{1}$, \\ ${ }^{1}$ Department of Botany, University of Dhaka, Dhaka 1000, Bangladesh \\ ${ }^{2}$ BIRDEM, Dhaka, Bangladesh \\ ${ }^{3}$ BCSIR Laboratories, Dhaka, Bangladesh
}

\begin{abstract}
Ex-situ culture studies of five selected aquatic macrophytes, namely Nymphaea nouchali Burm. f., Enhydra fluctuans Lour., Ipomoea aquatica Forsk., Hygroryza aristata (Retz.) Nees ex Wight \& Arn. and Limnocharis flava (L.) Buch. were carried out. Comparing the biochemical composition of the above mentioned five aquatic macrophytes, on an average, Enhydra fluctuans was found to contain highest amounts of proteins (18.20\%) and Ipomoea aquatica contains highest amounts of carbohydrate (58.60\%). Lowest amounts of proteins (14.35\%) were recorded in Hygroryza aristata and Limnocharis flava. On the other hand lowest amounts of carbohydrates were obtained in Nymphaea nouchali. Ipomoea aquatica contained highest amounts of energy $(321.23 \mathrm{kcal})$ and lowest amount was observed in Limnocharis flava. The five aquatic plants were low in fiber, fat and also in ash. Among all the five aquatic macrophytes, highest values of calcium and phosphorus were found to be present in Limnocharis flava and iron was highest in Nymphaea nouchali. Lowest values of calcium and phosphorus were present in Ipomoea aquatica and lowest amount of iron was present in Limnochris flava. The present study demonstrated that, these five aquatic macrophytes are the important sources of carbohydrate, protein and minerals, which are suitable for incorporation in human diet and feed also.
\end{abstract}

Key words: Biochemical composition, Aquatic macrophytes, Ex- situ culture

\section{Introduction}

Bangladesh, though very rich in wetland habitats with luxuriant growth of aquatic macrophytes, research work done in this field are not significant. Previous information of biochemical compositions of aquatic macrophytes are little. In Bangladesh, exsitu culture of different aquatic macrophytes were made by Alfasane et al. (2009, 2010 a,b,c,d and 2011) and biochemical composition of aquatic macrophytes, namely, Euryale ferox Salib., Nelumbo nucifera Gaertn. and Trapa bispinosa Roxb. were also studied by Alfasane et al. (2008, 2009 and 2011).

*Author for correspondence: Email: mujaddade@yahoo.com 
Bangladesh is an over populated country and the people cannot satisfy their nutritional requirements. Although rice is the staple food in our country, exploration of other food source is very essential. Macrophytes of Bangladesh can be used as the source of vegetable nutrients and minerals. In rural area maximum population use these macrophytes as source of vegetable. Cattle largely depend on some common aquatic macrophytes. Study on the chemical composition and their adaptation in different habitats of macrophytes is very much essential.

People of Bangladesh traditionally eat or use these macrophytes without having any detailed knowledge on the biochemical composition of their products, because there is very little information on this aspect of aquatic plants of Bangladesh. The natural habitats of the plant have been decreasing at a high rate. Considering this decline an ex situ culture studies of the plants for their conservation and at the same time to know their food values, the biochemical composition of some selected aquatic macrophytes, namely Nymphaea nouchali Burm. f., Enhydra fluctuants Lour., Ipomoea aquatica Forsk., Hygroryza aristata (Retz.) Nees ex Wight \& Arn., Limnocharis flava (L.) Buch. have been investigated.

\section{Materials and Methods}

The five species of aquatic macrophytes were selected and ex situ culture was made from June, 2011 to May, 2012 in the Botanical garden, Department of Botany, University of Dhaka (Figs. 1 - 5). Fresh leafy shoots of these species were collected for biochemical analyses. At first, these species were collected from the garden and then dried with the help of oven at $105^{\circ} \mathrm{C}$ for 5 hours. Then materials were crushed in a mortar with a pestle and the crushed materials were used to determine the amount of protein, carbohydrate, fat, moisture and ash contents according to the methods used by National Institute of Nutrition (1976). Moisture was determined with the help of a moisture meter (Chyo, Serial No.135252, 1B-30 CAPACITY) and protein was determined by Microkjeldhal method (National Institute of Nutrition 1976) . The ash content was determined in a Muffle furnace (CARBOLITE, Hope valley, S336RB, England, Serial No. 06/02/1539, Type-RHF 16/15). Digestion process of the ash was made for mineral contents. The ash after furnace is moistened with a small amount of glass-distilled water $(0.5-1.0 \mathrm{ml})$ and $2 \mathrm{ml}$ of conc. $\mathrm{HNO}_{3}$ acid added to it. The mixture is evaporated to dryness in a muffle furnace and calcium, phosphorus and iron were determined with the help of a UV Spectrophotometer (Cintra 6, Serial No. V 3681, GBC, National Institute of Nutrition 1976). Biochemical composition of the selected aquatic macrophytes was determined by the method of National Institute of Nutrition (1976). 


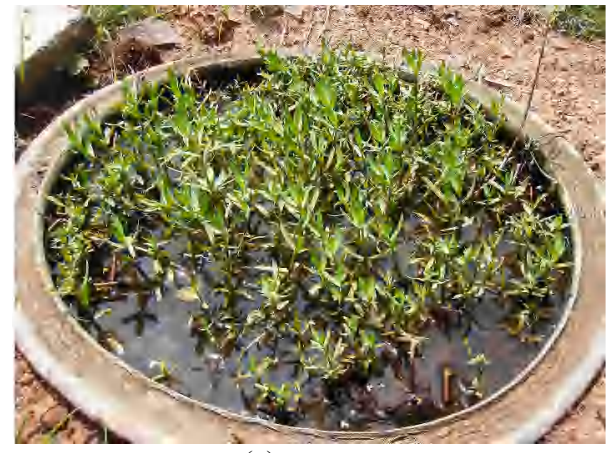

(a)

Fig.1a. Ex situ culture of Enhydra fluctuans in an earthen bin.

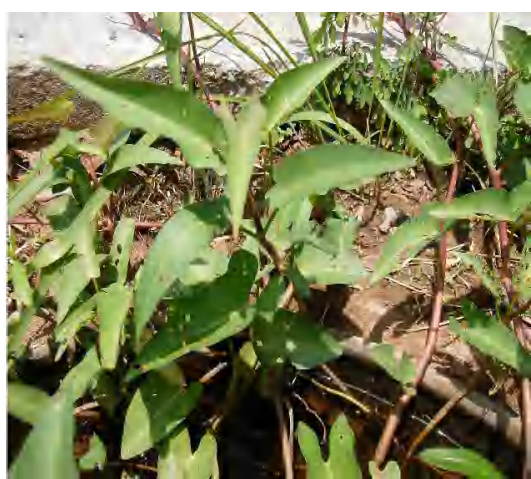

(a)

Fig. 2a. Ex situ culture of Ipomoea aquatica.

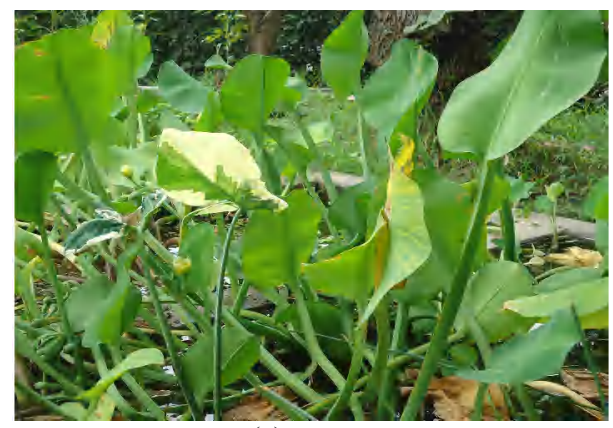

(a)

Fig. 3a. Ex situ culture of Limnocharis flava in the culture pit.

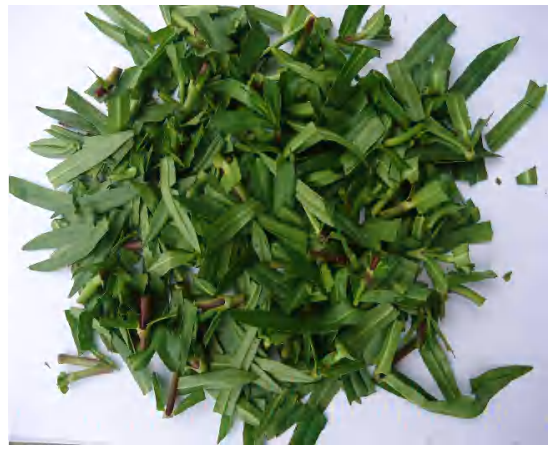

(b)

b. Many small cut pieces of Enhydra fluctuans.

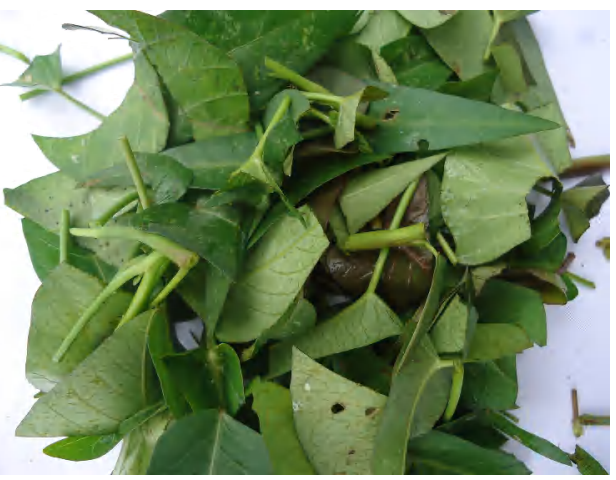

(b)

b. Ipomoea aquatica was chopped into many small pieces.

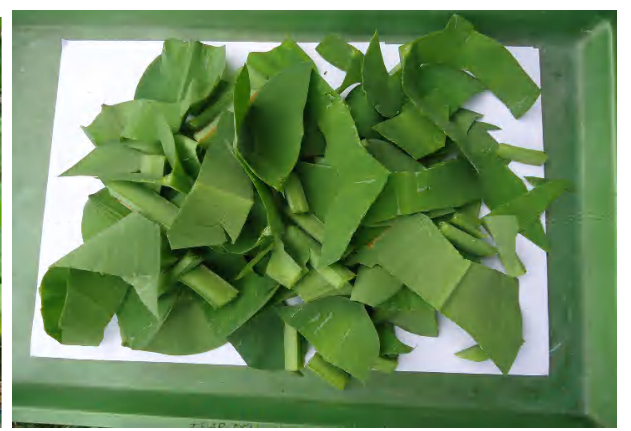

(b)

b. Leafy shoots of Limnocharis flava chopped into many pieces. 


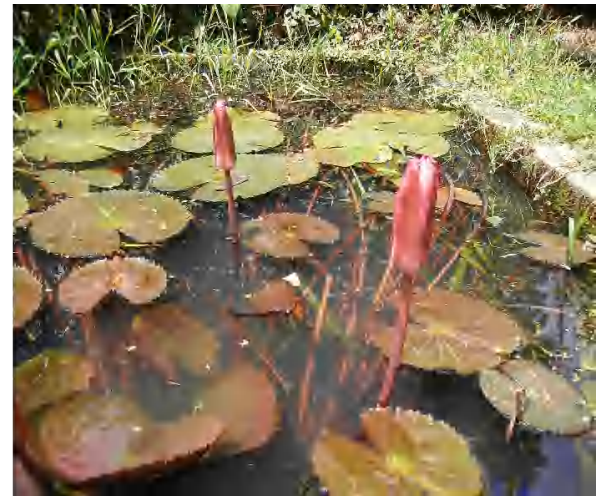

4(a)

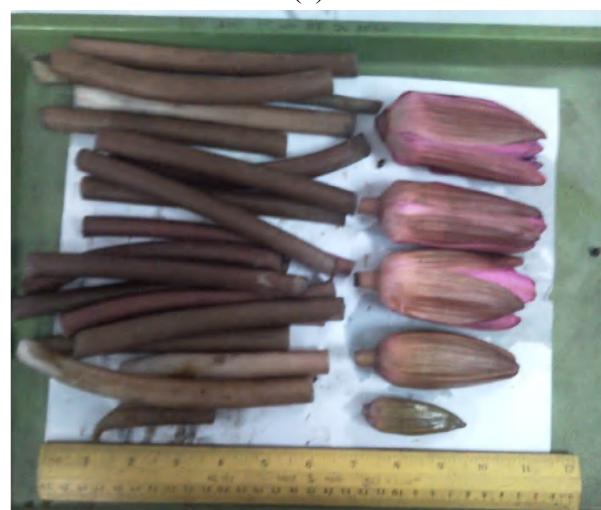

4(c)

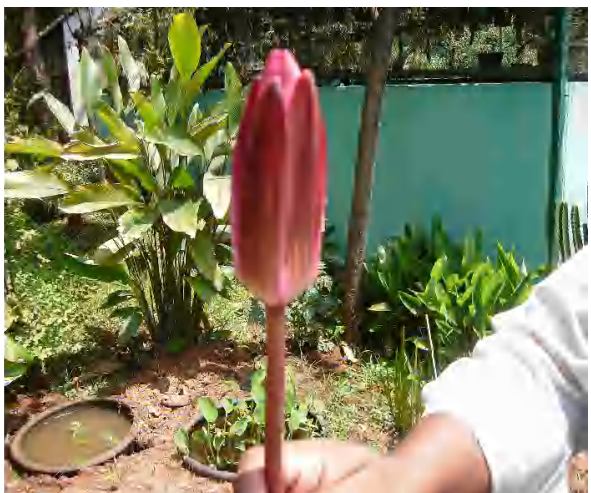

4 (b)

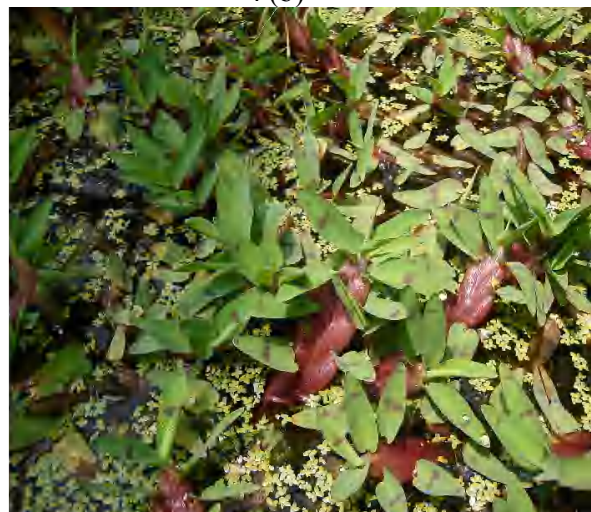

(5)

Figs 4a. Ex situ culture of Nymphaea nouchali in the culture pit. b. Red flower of Nymphaea nouchali with its long pedicel. c. Many small cut pieces of the pedicels of Nymphaea nouchali. 5. Ex situ culture of Hygroryza aristata in the culture pit.

\section{Results and Discussion}

Biochemical analyses of the biomass of Enhydra fluctuants showed that young shoots are extremely nutritious, containing $56.60 \%$ carbohydrate, $18.2 \%$ protein, $11.54 \%$ fibre, $14 \%$ ash and $1.14 \%$ fat. The mineral contents were $224.45 \mathrm{mg} / 100 \mathrm{~g}$ calcium, $175.22 \mathrm{mg} / 100 \mathrm{~g}$ phosphorus, $30.48 \mathrm{mg} / 100 \mathrm{~g}$ iron of dry weight of sample (Table 1). Enhydra fluctuans contained a significant amount of $\mathrm{P}$ in their leafy shoots. Dried plant materials produced $317.28 \mathrm{kcal} / 100 \mathrm{~g}$ of energy. Similar observations were also made by Dewanji et al. (1993). The tissue chemistry of aquatic plants has been reported to show considerable variation in mineral composition which may be attributed to the age and type of plants sampled, and the fertility of the aqueous environment (Boyd 1968.). When plants are considered as a feed source calcium and phosphorous ratio constitutes an important parameter. 
The biochemical analyses of Ipomaea aquatica showed that young shoots contained $58.60 \%$ carbohydrate, $16.8 \%$ protein, $10.30 \%$ moisture, $12.33 \%$ fibre, $13 \%$ ash and $1.30 \%$ fat. Dried plant materials were found to produce $321.2 \mathrm{kcal} / 100 \mathrm{~g}$ of energy. The mineral contents of this plant were as follows: calcium $128.26 \mathrm{mg} / 100 \mathrm{~g}$, phosphorus $173.22 \mathrm{mg} / 100 \mathrm{~g}$ and iron $27.70 \mathrm{mg} / 100 \mathrm{~g}$ on dry weight basis. In the present material protein and ash contents were more or less to the value obtained by Yadav and Agarwala (2011). According to them submerged plants having higher amounts of ash may be due to extraneous mineral deposition from surrounding habitats.

The biochemical analyses of Hygroriza aristata showed that young plants contained $58.10 \%$ carbohydrate, $14.35 \%$ protein, $12.70 \%$ moisture, $25 \%$ fibre, $13.86 \%$ ash and $1.00 \%$ fat (Table 2). In $100 \mathrm{~g}$ dry plant parts produced $306.34 \mathrm{kcal}$ of energy. The mineral content of $H$. aristata showed that they consist of $208.4 \mathrm{mg} / 100 \mathrm{~g}$ calcium, 228 $\mathrm{mg} / 100 \mathrm{~g}$ phosphorus and iron $20.58 \mathrm{mg} / 100 \mathrm{~g}$ on dry weight basis. Previously similar observation on biochemical analyses of seeds of Euryale ferox showed that seeds consisted of $61.2 \%$ carbohydrate, $15.6 \%$ protein, $1.3 \%$ fat, $7.6 \%$ fibre, $1.8 \%$ ash and $12.5 \%$ moisture on dry weight basis (Alfasane et al. 2008).

Pedicels of Nymphaea nouchali were found to contain $55.50 \%$ carbohydrate , $17.15 \%$ protein, $12.30 \%$ moisture, $23 \%$ fibre, $14 \%$ ash and $1.50 \%$ fat (Table 2). Dry pedicels produced $307.33 \mathrm{kcal} / 100 \mathrm{~g}$ of energy. The mineral contents of this plant were 328.66 $\mathrm{mg} / 100 \mathrm{~g}$ calcium, $250 \mathrm{mg} / 100 \mathrm{~g}$ phosphorus and $95.13 \mathrm{mg} / 100 \mathrm{~g}$ iron on dry weight basis. Another experiment on biochemical composition of seeds of another aquatic macrophyte namely, Nelumbo nucifera consisted of $63.8 \%$ carbohydrate, $16.4 \%$ protein, $1.6 \%$ fat, $4.5 \%$ fibre, $1.9 \%$ ash and $11.8 \%$ moisture on dry weight basis (Alfasane et al. 2009).

The proximate analyses of the species of Limnocharis flava showed that the leaves are nutritious, containing $57.3 \%$ carbohydrate , $14.35 \%$ protein, $13.10 \%$ moisture, $24 \%$ fibre, $14 \%$ ash and $1.25 \%$ fat (Table 1 ). Dry plants produced $305.39 \mathrm{kcal} / 100 \mathrm{~g}$ of energy. The amounts of calcium, phosphorus and iron were $493.18 \mathrm{mg} / 100 \mathrm{~g}, 262 \mathrm{mg} / 100 \mathrm{~g}$, and $17.94 \mathrm{mg} / 100 \mathrm{~g}$ in dry weight of sample (Tables 1 and 2). Biochemical analysis of fruits of Trapa bispinosa was found to contain $71.55 \%$ carbohydrate and $10.80 \%$ protein on dry weight basis. The percentage of moisture, fibre, ash and fat were 7.30, 6.35, 8.50 and 1.85, respectively (Alfasane et al. 2011).

Comparing the biochemical composition of above mentioned five aquatic macrophytes, on an average, E. fluctuants was found to contain highest amounts of proteins (18.20\%) and I. aquatica contained highest amounts of carbohydrate (58.60\%). Lowest amounts of proteins $(14.35 \%)$ were recorded in $H$. aristata and L. flava. On the other hand lowest 
amounts of carbohydrates were obtained in N. nouchali. I. aquatica was found to contain highest amounts of energy (321.23 kcal/100 g) and lowest was observed in L. flava. The five aquatic plants are low in fiber, fat and also in ash (Table 1).

Table 1. Comparison of proximate composition of five different aquatic macrophytes.

\begin{tabular}{llllll}
\hline \multirow{2}{*}{$\begin{array}{l}\text { Biochemical } \\
\text { composition }\end{array}$} & $\begin{array}{l}\text { Enhydra } \\
\text { fluctuants }\end{array}$ & $\begin{array}{l}\text { Ipomoea } \\
\text { aquatica }\end{array}$ & $\begin{array}{l}\text { Hygroryza } \\
\text { aristata }\end{array}$ & $\begin{array}{l}\text { Nymphaea } \\
\text { nouchali }\end{array}$ & $\begin{array}{l}\text { Limnocharis } \\
\text { flava }\end{array}$ \\
\hline Moisture (\%) & 10.06 & 10.30 & 12.70 & 12.30 & 13.10 \\
Ash (\%) & 14.00 & 13.00 & 13.86 & 14.00 & 14.00 \\
Protein (\%) & 18.20 & 16.80 & 14.35 & 17.15 & 14.35 \\
Fat (\%) & 1.14 & 1.30 & 1.00 & 1.05 & 1.25 \\
Fibre (\%) & 11.50 & 12.30 & 25.00 & 23.00 & 24.00 \\
Carbohydrate (\%) & 56.60 & 58.60 & 58.10 & 55.50 & 57.30 \\
$\begin{array}{l}\text { Energy } \\
\text { (Kcal/100 g) }\end{array}$ & 317.28 & 321.23 & 306.34 & 307.33 & 305.39 \\
\hline
\end{tabular}

Previously Alfasane et al. (2011) reported that the seeds of T. bispinosa contained 102.85 $\mathrm{mg}$ calcium, $3.8 \mathrm{mg}$ iron and $325 \mathrm{mg}$ phosphorus in 100 day mather. Dried seeds of T. bispinosa produced $354.85 \mathrm{kcal} / 100 \mathrm{~g}$ calories of energy.

Table 2. Comparison of mineral contents of different aquatic macrophytes.

\begin{tabular}{lccc}
\hline \multirow{2}{*}{$\begin{array}{l}\text { Name of the aquatic } \\
\text { macrophytes }\end{array}$} & \multicolumn{3}{c}{$\begin{array}{c}\text { Minerals } \\
(\mathrm{mg} / 100 \mathrm{~g})\end{array}$} \\
\cline { 2 - 4 } & Calcium & Phosphorus & Iron \\
\hline Enhydra fluctuants & 224.45 & 175.22 & 30.48 \\
Ipomoea aquatica & 128.26 & 173.22 & 27.7 \\
Hygroryza aristata & 208.4 & 228 & 20.58 \\
Nymphaea nouchali & 328.66 & 250 & 95.13 \\
Limnocharis flava & 493.18 & 262 & 17.94 \\
\hline
\end{tabular}

Among all the five aquatic macrophytes, highest values of calcium and phosphorus were found to be present in L. flava and iron was highest in N. nouchali. Lowest values of calcium and phosphorus were recorded in Ipomoea aquatica and iron was present in L. flava (Table 2). One hundred g dried seeds of Nelumbo nucifera produced 343.70 calories of energy. The seeds are low in fiber, very low in fat and also in ash but high in carbohydrates and also protein. Dharmananda (2002) had also reported biochemical composition of $N$. nucifera and showed that in $100 \mathrm{~g}$ (yielding about 350 calories of energy), there were 63 - 68 g carbohydrate (mostly starch), 17 - $18 \mathrm{~g}$ of protein, and only 1.9-2.5 $\mathrm{g}$ fat; the remaining one is water (about 13\%), and minerals (mainly sodium, 
potassium, calcium, and phosphorus). Regarding the chemical composition the values obtained in the present investigation are close to the range reported by Dharmandra (2002) and Yadav and Agarwala (2011). Read (1946) had also reported biochemical composition of Euryale ferox and showed the chemical compositions as carbohydrate $75.7 \%$, protein $9.9 \%$, fat $0.3 \%$, and ash $0.6 \%$. Howard-Williams and Junk (1977) studied the nutritional values of 27 Amazonian macrophyte species and found 5.3 $22.2 \%$ protein in the whole biomass on dry weight basis. The highest was found in Azolla microphylla Kaulf. and the lowest in Scleria secans (L.) Urb. and Rhynchospora gigantea Link.

Mineral nutrients are important aspects of nutritive quality. Execessive concentration of ash decreases the amount of organic constituents per unit weight and lowers food value. However, ash value below $15 \%$, is of little value in evaluating the nutritive value of a feed since it is the individual element that is important in the metabolic processes. On the basis of an overall nutrient composition, the plants were found to contain sufficient quantities of nutrients and thus are safe enough to be considered as potential livestock feed. The amount of carbohydrate was also significant as a source of energy. The present study has demonstrated that, these five aquatic macrophytes may be the important source of carbohydrate, protein and minerals, which are suitable for incorporation in human diet and feed also.

\section{References}

Alfasane, M.A, M. Khondker and M.M. Rahman. 2011. Biochemical composition of the fruits of water chestnut (Trapa bispinosa Roxb.). Dhaka Univ. J. Biol. Sci. 20(1): 95-98.

Alfasane, M.A., M. Khondker, Z.N.T. Begum, L.A. Banu, M.M. Rahman and U.F. Shahjadee. 2008. Fruit production and biochemical aspects of seeds of Euryale ferox Salisb. under ex-situ conditions. Bangladesh J. Bot. 37(2): 179-181.

Alfasane, M.A., M. Khondker and Z.N.T. Begum. 2009. Biochemical composition of the seeds of Nelumbo nucifera Gaertn. Dhaka Univ. J. Biol. Sci. 18(1): 83-85.

Alfasane, M.A., M. Khondker and Z.N.T. Begum. 2010a. Relationship between the growth of Euryale ferox Salisb. and some limnological parameters. Dhaka Univ. J. Biol. Sci. 19(1): 4146.

Alfasane, M.A., M. Khondker and Z.N.T. Begum. 2010b. Growth of water mimosa (Neptunia natans (L.f.) Druce) in relation to habitat limnology. J. Asiat. Soc. Bangladesh, Sci, 36(1): 75-81.

Alfasane, M.A., M. Khondker and Z.N.T. Begum. 2010c. Growth and regeneration of Cryptocoryne ciliata (Roxb.) Fisch. ex Wydler under ex-situ conditions. Bangladesh J. Bot. 39(1): 115-118.

Alfasane, M.A., M. Khondker and Z.N.T. Begum. 2010d. Effects of water depth on the growth of Nelumbo nucifera Gaertn. seedlings. Dhaka Univ. J. Biol. Sci. 19(2): 111-118.

Boyd, G.E. 1968. Fresh water plants: a potential source of protein. Economic Botany. 22:359-368.

Dewanji, A, S. Matai, L. Si and S. Barik. 1993. Chemical composition of two semi-aquatic plants for food use, Plant Foods for Human Nutrition 44(1): 11-16.

Dharmananda, S. 2002. Lotus seed, food and medicine. March, 2002, [Online] as retrieved on 30 May 2008 15:05:19 GMT (Cited 2008 Jun 05). Available from: URL: http:// www. 
itmonline.org/arts/lotus.htm.

Howard-Williams, C. and Junk, W. J. 1977. The chemical composition of central Amazonian aquatic macrophytes with special reference to their role in the ecosystem. Arch. Hydrobiol. 79(4): 446-464.

National Institute of Nutrition. 1976. A manual of laboratory techniques, National Institute of Nutrition, Indian Council of Medical Research, Hyderabad- 500007, India. pp. 123.

Read, B. E. (ed.). 1946. Famine foods listed in the Chiu huang pen ts'ao [of Ting Wang Chou]: giving their identity, nutritional values and notes on their preparation. Shanghai, China: Henry Lester Insitute of Medical Research. 93 pp., Famine Foods, Compiled by Robert Freedman, NYMPHAEACEAE, [Online], Last update Thursday, March 5, 1998, (cited 2008 Jun 05). Available from: URL: http://www. hort.purdue.edu/newcrop/faminefoods/ff families/ NYMPHAEACEAE.html

Yadav, R.N.S. and M. Agarwala, 2011. Phytochemical analysis of some medicinal plants, J. Phytology, 3(12): 39-47.

(Revised copy received on 22.4.2018) 